\title{
Chemical composition and acaricidal activity of essential oils from Peperomia pellucida Kunth. against Tetranychus urticae
}

\author{
de Oliveira, J. C. S.;* da Camara, C. A. G.; Neves, R. C. S.; Botelho, P. S.
}

Rev. Virtual Quim., 2017, 9 (6), 2204-2213. Data de publicação na Web: 20 de setembro de 2017

\author{
http://rvq.sbq.org.br
}

\section{Composição química e atividade acaricida dos óleos essenciais de Peperomia pellucida Kunth. contra Tetranychus urticae}

Resumo: Os óleos essenciais obtidos por hidrodestilação das folhas e caules de Peperomia pellucida coletadas de um fragmento de Mata Atlântica no estado da Bahia, Brasil, foram analisados utilizando cromatografia gasosa (CG) e cromatografia gasosa acoplada à espectrometria de massas (CG-EM). Independentemente da parte da planta, sesquiterpenos foram a classe de compostos mais abundantes nos óleos, seguido de fenilpropanoides. Os principais constituintes do óleo das folhas foram $\gamma$-gurjuneno $(11,34 \% \pm 0,01), 1,10$-di-epi-cubenol $(11,27 \% \pm 0,02)$, $(E)$-cariofileno $(8,71 \% \pm 0,02)$ e dilapiol $(8,50 \% \pm 0,03)$, enquanto que carotol $(9,77 \% \pm 0,01)$, dilapiol $(9,18 \% \pm 0,01)$, trans- $\beta$-guaieno $(9,05 \% \pm 0,02)$ e $(E)$ cariofileno $(8,53 \% \pm 0,02)$ foram os principais constituintes do óleo do caule. A atividade dos óleos contra Tetranychus urticae foi avaliada por $24 \mathrm{~h}$. O óleo do caule $\left(\mathrm{CL}_{50}=1 \times 10^{-2} \mu \mathrm{L} / \mathrm{L}\right.$ de ar) foi quatro vezes mais tóxico do que o óleo de folha $\left(\mathrm{CL}_{50}=4 \times 10^{-2} \mu \mathrm{L} / \mathrm{L}\right.$ de ar), mas 2,5 vezes menos ativo do que o eugenol, o qual foi utilizado como o controle positivo. Este estudo revelou diferentes perfis químicos para os óleos da folha e caule e reporta pela primeira vez a ação acaricida do óleo essencial de $P$. pellucida contra uma importante praga agrícola.

Palavras-chave: Peperomia pellucida; Tetranychus urticae; sesquiterpeno; fenilpropanoide; $\gamma^{-}$ gurjunene; carotol.

\section{Abstract}

Essential oils obtained through hydrodistillation of the leaves and stems of Peperomia pellucida collected from a fragment of the Atlantic Forest in the state of Bahia, Brazil, were analyzed using gas chromatography (GC) and gas chromatography-mass spectrometry (GC-MS). Independently of the part of the plant, sesquiterpenes were the most abundant class of compounds in the oils, followed by phenylpropanoids. The main constituents in the leaf oil were $\gamma$-gurjunene $(11.34 \% \pm 0.01), 1,10$-di-epicubenol (11.27\% \pm 0.02$)$, (E)-caryophyllene $(8.71 \% \pm 0.02)$ and dillapiole $(8.50 \% \pm 0.03)$. The major constituents of the stem oil were carotol $(9.77 \% \pm 0.01)$, dillapiole $(9.18 \% \pm 0.01)$, trans- $\beta$-guaiene $(9.05 \% \pm 0.02)$ and $(E)$-caryophyllene $(8.53 \% \pm 0.02)$. The activity of the oils against Tetranychus urticae was evaluated for $24 \mathrm{~h}$. The stem oil ( $\mathrm{LC}_{50}=1 \times 10^{-2} \mu \mathrm{L} / \mathrm{L}$ of air) was fourfold more toxic than the leaf oil $\left(\mathrm{LC}_{50}=4 \times 10^{-2} \mu \mathrm{L} / \mathrm{L}\right.$ of air), but 2.5 -fold less active than eugenol, which was used as the positive control. This study revealed different chemical profiles for the leaf and stem oils and is the first report of the acaricidal activity of $P$. pellucida essential oil against an important agricultural pest.

Keywords: Peperomia pellucida; Tetranychus urticae; sesquiterpene; phenylpropanoid; ү-gurjunene; carotol.

\footnotetext{
* Universidade Federal Rural de Pernambuco, Departamento de Química, Campus Recife, CEP 52171-900, Recife-PE, Brazil.

M candidoselva@hotmail.com DOI: $10.21577 / 1984-6835.20170130$
} 


\section{Chemical composition and acaricidal activity of essential oils from Peperomia pellucida Kunth. against Tetranychus urticae José C. S. de Oliveira, ${ }^{*}$ Claudio A. G. da Camara, Roberta C. S. Neves, Priscilla S. Botelho}

Universidade Federal Rural de Pernambuco, Departamento de Química, Campus Recife, CEP 52171-900, Recife-PE, Brazil.

*candidoselva@hotmail.com

\section{Introduction}

\section{Experimental}

2.1. Collection of plant material

2.2. Isolation of the essential oil

2.3. Gas chromatography - Gas chromatography - mass spectrometry analyses

2.4. Mites

2.5. Fumigant assay

\section{Results and discussion}

\section{Introduction}

The family Piperaceae is composed of five genera and approximately 1400 species of plants. Peperomia is the second largest genus of the family, with more than 1000 species, ${ }^{1}$ 600 of which are distributed throughout Brazil. $^{2}$ Peperomia pellucida Kunth. is a herbaceous plant with succulent leaves that has a strong mustard scent and grows in moist soils as well as the cracks of wet rocks. In northeastern Brazil, this plant is commonly known as "favaquinha", "alfavaca", "línguade-sapo", "coraçãozinho" and "erva-dejaboti" and is used in folk medicine for the treatment of abscesses, skin diseases and conjunctivitis. ${ }^{3,4}$

The literature offers studies on organic extracts derived from $P$. pellucida that demonstrate the potential of this plant for the treatment of bone fractures ${ }^{5}$ as well as anti-cancer, $^{3}$ antisickling, ${ }^{1}$ antimoebic, ${ }^{6}$ bactericide, ${ }^{7}$ antioxidant, ${ }^{8}$ analgesic and antiinflammatory properties. ${ }^{9-10}$ According to phytochemical studies, the biological properties of this plant are related to the presence of alkaloids, tannins, flavonoids, saponin and cardiac glycosides. ${ }^{1}$

A survey of the literature reveals the composition of the essential oil from $P$. pellucida in different parts of the world ${ }^{11-13}$ as well as two regions in Brazil. ${ }^{14-15}$ With the exception of the characterization of the leaf oil from plants collected in Cameroon ${ }^{12}$ and the root oil from plants collected in India, ${ }^{13}$ the determination of the chemical composition of $P$. pellucida oils has been 
performed using the entire plant, with no distinction of its parts (leaves and stems). The literature also reports the potential of $P$. pellucida oil as an antifungal agent, ${ }^{12}$ bactericide and antioxidant. ${ }^{11}$ To the best of our knowledge, the acaricidal effect of the essential oil from $P$. pellucida against an important agricultural pest, Tetranychus urticae, has not yet been scientifically demonstrated and no characterization of the stem oil has been performed.

The two-spotted spider mite, $T$. urticae Koch, is a polyphagous species and a major agricultural pest in the world. ${ }^{16}$ In Brazil, this mite causes serious harm on irrigated plantations and in closed environments, such as greenhouses, leading to significant economic losses. Due to their highly volatile nature, essential oils can be used in pest control processes in closed environments. ${ }^{17}$ Our research group has recently intensified studies in search of natural substances with acaricidal properties as an alternative to conventional acaricidal agents for the control of mites of agricultural interest. ${ }^{18-20}$

Therefore, as part of systematic research of the aromatic flora and acaricidal activity of plants that grow wild in fragments of the Atlantic Forest in northeastern Brazil, ${ }^{18-21}$ the focus of the present study was the chemical composition and acaricidal activity of leaf and stem oils from $P$. pellucida growing wild in a fragment of the Atlantic Forest in the city of Salvador, state of Bahia, Brazil.

\section{Experimental}

\subsection{Collection of plant material}

Fresh leaves and stem from $P$. pellucida were collected, at $45 \mathrm{~m}$ elevation relative to sea level in October 2009 at morning from a fragment of Atlantic Forest located in municipally of Salvador - Bahia, Brazil (geographical coordinates of collection site $=$ 12059'41.90" S e 3830'54.73" O). The plant was identified by Dr. Maria Rita Cabral Sales de Melo from Universidade Federal Rural de Pernambuco. Voucher specimen was deposited in the Vasconcelos Sobrinho Herbarium of the Universidade Federal Rural de Pernambuco, under the number $\# 48090$.

\subsection{Isolation of the essential oil}

The essential oils from fresh leaves and stem $(100 \mathrm{~g})$ were obtained by hydrodistillation using a modified Clevenger apparatus for $2 \mathrm{~h}$. The oil layers were separated by density differences and dried over anhydrous sodium sulfate, stored in hermetically sealed glass containers, and kept under refrigeration at $\mathrm{O} \stackrel{\mathrm{O}}{\mathrm{C}}$ until analysis and acaricidal assay. Total oil yields were expressed as percentages $(\mathrm{g} / 100 \mathrm{~g}$ of fresh plant material). All experiments were carried out in triplicate.

2.3. Gas chromatography - Gas chromatography-mass spectrometry analyses

Quantitative GC analyses were carried out using a Hewlett Packard 5890 Series II GC apparatus equipped with a flame ionization detector (FID) and a non-polar DB-5 fused silica capillary column $(30 \mathrm{~m} \times 0.25 \mathrm{~mm} \times 0.25$ $\mathrm{mm}$ film thickness) (J \& W Scientific). The oven temperature was programmed from 50 to $250 \stackrel{\circ}{\circ}$ at a rate $3 \stackrel{\circ}{\circ} / \mathrm{min}$ for integration purposes. Injector and detector temperatures were at $250 \stackrel{\circ}{ } \mathrm{C}$. Hydrogen was used as the carrier gas at a flow rate of 1 $\mathrm{L} / \mathrm{min}$ and 30 p.s.i. inlet pressure in split mode (1:30). The injection volume was 0.5 $\mathrm{mL}$ of diluted solution (1/100) of oil in $n$ hexane. The amount of each compound was calculated from GC peak areas in the order of DB-5 column elution and expressed as a relative percentage of the total area of the chromatograms. Analyses were carried out in triplicate.

The qualitative GC-MS analysis was performed with a Hewlett Packard GC-MS 
(CG: 5890 SERIES II/CG-MS: MSD 5971) system operating in the $\mathrm{El}$ mode at $70 \mathrm{eV}$ fitted with the same column and temperature program as that for the GC experiments, with the following parameters: carrier gas $1 / 4$ helium; flow rate $1 / 41 \mathrm{~mL} / \mathrm{min}$; split mode (1:30); injected volume $1 / 41 \mathrm{~mL}$ of diluted solution (1/ 10) of oil in $n$-hexane. Identification of the components was based on $\mathrm{GC}$ retention indices with reference to a homologous series of $\mathrm{C}_{11}-\mathrm{C}_{24} \quad n$-alkanes calculated using the Van den Dool and Kratz equation ${ }^{22}$ and by computer matching against the mass spectral library of the GC-MS data system (NIST 98 and WILEY) and co-injection with authentic standards as well as other published mass spectra. ${ }^{23}$ Area percentages were obtained electronically from the GC-FID response without the use of an internal standard or correction factors.

\subsection{Mites}

Mites (T. urticae) used for the bioassay were obtained from a lab colony at the Laboratório de Inseticidas Naturais of the Agronomy Department - Universidade Federal Rural de Pernambuco. They were reared on plants of Canavalia ensiformes $\mathrm{L}$. (jack bean) at $25 \pm 5 \stackrel{\circ}{\circ}, 65 \pm 5 \% \mathrm{RH}$ and a 12:12 h photophase.

\subsection{Fumigant assay}

The fumigant method was the same as that used by Araújo et al. ${ }^{18}$ Glass recipients with a capacity of $2.5 \mathrm{~L}$ were used as test chambers. Female spider mites on $C$. ensiformes leaf disks $2.5 \mathrm{~cm}$ in diameter were exposed to the Peperomia oils. A fine brush was used to transfer the mites onto the leaf disks. In order to maintain the turgor of the disks and avoid the escape of mites, the leaf disks were placed onto filter paper disks saturated with water in Petri dishes $(9 \mathrm{~cm})$.
The experiments were performed in triplicate. One replicate consisted of 30 specimens of $T$. urticae placed on 3 leaf disks (10 mites per disk) in a Petri dish. The oils were applied with an automatic pipette on a piece of filter paper $(5 \times 3 \mathrm{~cm})$ attached to the underside of the recipient lid. The concentration of the Peperomia oils used in the bioassays ranged from 0.01 to $1.5 \mu \mathrm{L} / \mathrm{L}$ air and that of the natural fumigant eugenol ranged from $6.4 \times 10^{-5}$ to $1.2 \mu \mathrm{L} / \mathrm{L}$ air. Negative control, glass recipients contained no essential oil or other products. Mortality was determined after $24 \mathrm{~h}$. Following exposure, the Petri dishes with spider mites were then removed from the recipients and the mites were touched lightly with a brush in order to determine mortality. Those with no sign of movement were considered dead. The mortality data for Peperomia oils and eugenol were analyzed with the Probit model using the POLO-PC software for the determination of $\mathrm{LC}_{50}$ values, with $95 \%$ confidence levels determined all experiments. ${ }^{24}$

\section{Results and discussion}

Hydrodistillation of the leaves and stems of $P$. pellucida led to the acquisition of yellowish oils. The yield of the leaf oil was significantly greater than that of the stem oil $(0.09 \% \pm 0.01$ and $0.02 \% \pm 0.01$, respectively). Such yields are lower than those reported by Silva et al. ${ }^{14}$ but the authors cited employed a twofold longer extraction time than that employed in the present study and the aerial parts (leaves and stems) were the vegetal matrix used. A total of 72 substances were identified, accounting for $91.66 \% \pm 0.24$ and $91.85 \% \pm 0.01$ of the chemical composition of the leaf and stem oils, respectively. The volatile components identified in these oils are indicated in Table 1 in the order of elution on the DB-5 column. 
de Oliveira, J. C. S. et al.

Table 1. Percentage of volatile components identified in leaf and stem essential oils of $P$. pellucida

\begin{tabular}{|c|c|c|c|c|}
\hline \multirow[t]{2}{*}{ Compound } & \multirow[t]{2}{*}{$\mathbf{R I}^{\mathrm{a}}$} & \multirow[t]{2}{*}{$\mathbf{R \mathbf { I } ^ { \mathbf { b } }}$} & \multicolumn{2}{|c|}{ Relative $\% \pm S D$} \\
\hline & & & Leaves & Stem \\
\hline Limonene $^{\mathrm{M}}$ & 1030 & 1031 & $0.07 \pm 0.01$ & $0.05 \pm 0.01$ \\
\hline (Z)-6-Ocimene ${ }^{\mathrm{M}}$ & 1034 & 1037 & $0.04 \pm 0.00$ & - \\
\hline (E)-B-Ocimene ${ }^{\mathrm{M}}$ & 1045 & 1050 & $0.20 \pm 0.01$ & - \\
\hline$\gamma$-Terpinene ${ }^{M}$ & 1058 & 1059 & - & $0.02 \pm 0.01$ \\
\hline Fenchone $^{\mathrm{M}}$ & 1084 & 1086 & - & $0.04 \pm 0.01$ \\
\hline Linalool $^{\mathrm{M}}$ & 1095 & 1096 & $0.26 \pm 0.01$ & $0.13 \pm 0.01$ \\
\hline$n$-Nonanal ${ }^{\mathrm{Fa}}$ & 1101 & 1100 & $0.41 \pm 0.01$ & - \\
\hline Nopinone $^{\mathrm{M}}$ & 1141 & 1140 & - & $0.04 \pm 0.01$ \\
\hline Hexyl butanoate $\mathrm{Fa}^{\mathrm{Fa}}$ & 1189 & 1192 & $0.52 \pm 0.01$ & - \\
\hline Dihydro-citronellol $^{\mathrm{M}}$ & 1204 & 1195 & $3.32 \pm 0.02$ & - \\
\hline trans-Piperitol $^{\mathrm{M}}$ & 1209 & 1208 & - & $0.03 \pm 0.01$ \\
\hline Dihydro myrcenol acetate ${ }^{\mathrm{M}}$ & 1212 & 1215 & $5.20 \pm 0.01$ & - \\
\hline Hexyl 2-methyl butanoate ${ }^{\mathrm{Fa}}$ & 1235 & 1236 & $0.41 \pm 0.02$ & - \\
\hline 2-(E)-Decenal ${ }^{\mathrm{Fa}}$ & 1260 & 1263 & - & $0.02 \pm 0.01$ \\
\hline trans-Linalool oxide acetate ${ }^{\mathrm{M}}$ & 1284 & 1288 & - & $0.04 \pm 0.01$ \\
\hline Terpinen-4-ol acetate ${ }^{\mathrm{M}}$ & 1297 & 1299 & - & $0.20 \pm 0.01$ \\
\hline$n$-Tridecane $\mathrm{Fa}^{\mathrm{Fa}}$ & 1301 & 1300 & - & $0.04 \pm 0.01$ \\
\hline$\delta$-Elemene $\mathrm{s}^{\mathrm{s}}$ & 1338 & 1338 & $0.12 \pm 0.01$ & $0.02 \pm 0.01)$ \\
\hline$\alpha$-Cubebene ${ }^{\mathrm{s}}$ & 1351 & 1348 & - & $0.09 \pm 0.01$ \\
\hline Eugenol $^{\mathrm{P}}$ & 1362 & 1359 & $0.08 \pm 0.01$ & $0.11 \pm 0.01$ \\
\hline Cyclosativene $^{\mathrm{S}}$ & 1374 & 1371 & - & $0.04 \pm 0.01$ \\
\hline Isoledene ${ }^{\mathrm{S}}$ & 1375 & 1376 & - & $0.07 \pm 0.01$ \\
\hline Longicyclene $^{\mathrm{S}}$ & 1377 & 1374 & - & $0.03 \pm 0.01$ \\
\hline$\alpha$-Copaene $e^{\mathrm{s}}$ & 1378 & 1376 & - & $0.02 \pm 0.01$ \\
\hline Daucene $\mathrm{s}^{\mathrm{s}}$ & 1381 & 1381 & $0.56 \pm 0.01$ & $0.62 \pm 0.01$ \\
\hline B-Bourbonene ${ }^{\mathrm{s}}$ & 1387 & 1388 & $1.46 \pm 0.02$ & $1.30 \pm 0.01$ \\
\hline B-Elemene ${ }^{\mathrm{s}}$ & 1393 & 1390 & - & $0.46 \pm 0.01$ \\
\hline (Z)-Jasmone $\mathrm{M}^{\mathrm{M}}$ & 1395 & 1392 & $3.27 \pm 0.01$ & - \\
\hline Decyl acetate $\mathrm{Fa}^{\mathrm{Fa}}$ & 1410 & 1408 & $1.69 \pm 0.01$ & - \\
\hline$\alpha$-Santalene ${ }^{s}$ & 1415 & 1417 & $0.18 \pm 0.01$ & - \\
\hline$(E)$-Caryophyllene ${ }^{\mathrm{s}}$ & 1420 & 1419 & $8.71 \pm 0.02$ & $8.53 \pm 0.02$ \\
\hline
\end{tabular}




\begin{tabular}{|c|c|c|c|c|}
\hline B-Gurjunene ${ }^{\mathrm{S}}$ & 1431 & 1433 & $0.18 \pm 0.01$ & $1.24 \pm 0.01$ \\
\hline Aromadendrene $^{\mathrm{s}}$ & 1446 & 1441 & $0.44 \pm 0.02$ & - \\
\hline$(E)$-Cinnamic acid ${ }^{\mathrm{P}}$ & 1456 & 1454 & $0.28 \pm 0.01$ & - \\
\hline$\alpha$-Humulene ${ }^{\mathrm{S}}$ & 1459 & 1454 & $0.36 \pm 0.01$ & - \\
\hline$\alpha$-Patchoulene ${ }^{\mathrm{S}}$ & 1463 & 1456 & - & $0.11 \pm 0.01$ \\
\hline Seychellene ${ }^{\mathrm{S}}$ & 1467 & 1460 & $0.72 \pm 0.01$ & $6.66 \pm 0.01$ \\
\hline Allo-Aromadendrene ${ }^{S}$ & 1468 & 1460 & - & $0.42 \pm 0.01$ \\
\hline 9-epi-(E)-Caryophylene ${ }^{S}$ & 1470 & 1466 & - & $1.76 \pm 0.01$ \\
\hline$\gamma$-Gurjunene $e^{s}$ & 1473 & 1477 & $11.34 \pm 0.01$ & $8.42 \pm 0.02$ \\
\hline$\gamma$-Muurolene ${ }^{\mathrm{S}}$ & 1481 & 1479 & - & $2.33 \pm 0.02$ \\
\hline Germacrene $D^{S}$ & 1485 & 1485 & $4.98 \pm 0.01$ & $1.07 \pm 0.01$ \\
\hline 6-Selinene ${ }^{\mathrm{S}}$ & 1491 & 1490 & - & $1.15 \pm 0.01$ \\
\hline cis-B-Guaiene $^{\mathrm{s}}$ & 1490 & 1493 & $1.16 \pm 0.01$ & - \\
\hline Valencene $^{\mathrm{S}}$ & 1493 & 1496 & - & $1.11 \pm 0.01$ \\
\hline Viridiflorene $^{\mathrm{s}}$ & 1498 & 1496 & $1.86 \pm 0.01$ & - \\
\hline Bicyclogermacrene $^{\mathrm{s}}$ & 1503 & 1500 & $4.11 \pm 0.01$ & - \\
\hline trans-6-Guaiene ${ }^{s}$ & 1506 & 1502 & - & $9.05 \pm 0.02$ \\
\hline$(E, E)-\alpha$-Farnesene $\mathrm{s}^{\mathrm{s}}$ & 1510 & 1505 & $2.72 \pm 0.01$ & - \\
\hline$(Z)-\gamma$-Bisabolene ${ }^{\mathrm{s}}$ & 1512 & 1515 & - & $2.89 \pm 0.01$ \\
\hline Myristicin $^{P}$ & 1515 & 1518 & $0.52 \pm 0.01$ & $1.66 \pm 0.01$ \\
\hline 7-epi- $\alpha$-Selinene ${ }^{S}$ & 1519 & 1522 & - & $2.23 \pm 0.01$ \\
\hline B-Sesquiphellandrene ${ }^{\mathrm{S}}$ & 1525 & 1522 & $1.37 \pm 0.01$ & - \\
\hline$\delta$-Cadinene $\mathrm{S}^{\mathrm{S}}$ & 1529 & 1523 & $0.36 \pm 0.01$ & $5.06 \pm 0.01$ \\
\hline$\alpha$-Cadinene ${ }^{\mathrm{S}}$ & 1541 & 1538 & - & $1.24 \pm 0.01$ \\
\hline$\alpha$-Calacorene ${ }^{\mathrm{S}}$ & 1544 & 1545 & - & $0.18 \pm 0.01$ \\
\hline Elemicin $^{p}$ & 1554 & 1557 & - & $0.35 \pm 0.01$ \\
\hline epi-Longipinanol ${ }^{\mathrm{s}}$ & 1562 & 1563 & $0.41 \pm 0.01$ & - \\
\hline$(Z)$-Isoelemicin ${ }^{P}$ & 1567 & 1570 & $3.86 \pm 0.02$ & - \\
\hline Caryophyllene oxide ${ }^{\mathrm{s}}$ & 1587 & 1583 & $0.74 \pm 0.01$ & $2.87 \pm 0.01$ \\
\hline B-Copaen-4- $\alpha$-ol ${ }^{\mathrm{S}}$ & 1592 & 1590 & $2.00 \pm 0.02$ & - \\
\hline Carotol $^{\mathrm{s}}$ & 1599 & 1594 & - & $9.77 \pm 0.01$ \\
\hline 1,10-Di-epi-Cubenol ${ }^{\mathrm{S}}$ & 1613 & 1619 & $11.27 \pm 0.02$ & - \\
\hline Dill apiole ${ }^{p}$ & 1625 & 1620 & $8.50 \pm 0.03$ & $9.18 \pm 0.01$ \\
\hline Cedr-8(15)-en-9- $\alpha$-ol $\left.\right|^{\mathrm{s}}$ & 1654 & 1651 & $0.72 \pm 0.01$ & $1.53 \pm 0.01$ \\
\hline
\end{tabular}




\begin{tabular}{ccccc}
\hline Himachalol $^{\mathrm{s}}$ & 1662 & 1653 & $0.70 \pm 0.01$ & $0.99 \pm 0.01$ \\
Selin-11-en-4- $\alpha$-ol $^{\mathrm{s}}$ & 1666 & 1659 & $0.33 \pm 0.01$ & - \\
$\begin{array}{c}\text { (E)-Citronellyl tiglate } \\
\text { s }\end{array}$ & 1670 & 1668 & $0.78 \pm 0.01$ & - \\
Bulnesol $^{\mathrm{s}}$ & 1673 & 1671 & - & $1.10 \pm 0.01$ \\
Apiole $^{\mathrm{p}}$ & $\mathbf{1 6 8 4}$ & $\mathbf{1 6 7 8}$ & $\mathbf{4 . 0 1} \pm 0.03$ & $\mathbf{7 . 5 8 \pm 0 . 0 2}$ \\
Iso-Longifolol $^{\mathrm{s}}$ & 1739 & 1729 & $0.63 \pm 0.01$ & - \\
b-Vetivone $^{\mathrm{s}}$ & 1836 & 1823 & $0.81 \pm 0.01$ & - \\
\hline Total & & & $\mathbf{9 1 . 6 6 \pm 0 . 2 4}$ & $\mathbf{9 1 . 8 5} \pm 0.01$
\end{tabular}

a Retention Index calculated by co-injection of a homologous series of $n$ - alkanes using nonpolar DB-5 capillary column; ${ }^{b}$ Retention Index from literature; $\mathrm{M}=$ monoterpenes; $\mathrm{S}=$ sesquiterpenes; $\mathrm{P}=$ Phenylpropanoids, $\mathrm{Fa}=$ Fatty acid derivatives and $\mathrm{SD}=$ Standard deviation .

As established by Knudsen et al., ${ }^{25}$ the compounds were grouped into three classes, to facilitate the visualization of the volatile compounds characterized in the leaf and stem oils: isoprenoids, phenylpropanoids and fatty acid derivatives. Considering isoprenoids, both oils had high contents of sesquiterpenes $(72.36 \% \pm 0.04$ of the stem oil and $59.02 \% \pm 0.18$ of the leaf oil). Phenylpropanoids were the second most abundant chemical class $(18.88 \% \pm 0.02$ of the stem oil and $17.25 \% \pm 0.10$ of the leaf oil). Silva et al. ${ }^{14}$ and Moreira et al. ${ }^{15}$ respectively found that phenylpropanoids were the predominant class in essential oils from $P$. pellucida growing in northern region (city of Belém) southeastern region (city of Rio de Janeiro) of Brazil, respectively.

The percentage of monoterpenes was significant only in the leaf oil $(12.36 \% \pm 0.05)$. Carboxyl acid derivatives were another chemical class found in the essential oil of $P$. pellucida growing in the city of Salvador, state of Bahia $(3.03 \% \pm 0.00$ of the leaf oil and $0.06 \% \pm 0.00$ of the stem oil). Although sesquiterpenes were the main chemical class in the essential oils, the chemical profiles of the leaves and stems differed both qualitatively and quantitatively. Among the 72 compounds identified, only 18 were found in both parts of the plant, with significant percentages of $\gamma$-gurjunene $(11.34 \% \pm 0.01$ and $8.42 \% \pm 0.02$ of the leaf and stem oil, respectively), dillapiole $(8.50 \% \pm 0.03$ and
$9.18 \% \pm 0.01$ of the leaf and stem oil, respectively) and apiole $(4.01 \% \pm 0.03$ and $7.58 \% \pm 0.02$ of the leaf and stem oil, respectively).

The sesquiterpene carotol was absent from the leaf oil, but was the major component of the stem oil $(9.77 \% \pm 0.01)$, followed by dillapiole $(9.18 \% \pm 0.01)$. These findings are in agreement with data reported by Verma et al. ${ }^{13}$ who also found that carotol was the main component of the aerial parts of a sample from India, followed by dillapiole. However, the phenylpropanoid dillapiole is reported to be the main component of the aerial parts in other samples collected in Brazil (39.7\% - city of Belém; ${ }^{14} 36.9 \%$ - city of Rio de Janeiro) ${ }^{15}$ and Nigeria (38.6\%). ${ }^{26}$ Dillapiole has also been reported as the main component of leaf oil $(37.8 \%)^{12}$ and root oil $(63.9 \%)^{13}$ from plants collected in Cameroon and India, respectively. trans- $\beta$-Guaiene (9.05\% \pm 0.02$), \quad(E)$-caryophyllene $(8.53 \% \pm 0.02), \gamma$-gurjunene $(8.42 \% \pm 0.02)$ and apiole $(7.58 \% \pm 0.02)$ are other components found in significant quantities in the stem oil of $P$. pellucida growing in the city of Salvador, state of Bahia, among which (E)caryophyllene and apiole have previously been reported in samples collected in $\mathrm{Brazil}^{14}$ and India, ${ }^{13}$ respectively.

The major components of the leaf oil were $\gamma$-gurjunene $(11.34 \% \pm 0.01)$ and 1,10-di-epicubenol $(11.27 \% \pm 0.02)$, followed by $(E)$ caryophyllene $\quad(8.71 \% \pm 0.02), \quad$ dillapiole 
$(8.50 \% \pm 0.03)$ and apiole $(4.01 \% \pm 0.03)$. These findings are in disagreement with data described by François et al., ${ }^{12}$ who found that dillapiole and myristicine were the major components of the leaf oil of a sample collected in Cameroon. However, these phenylpropanoids were found in the leaf and stem oils from $P$. pellucida in the present study (dillapiole: $8.50 \% \pm 0.03$ and $9.18 \% \pm 0.01$, respectively; myristicine: $0.52 \% \pm 0.01$ and $1.66 \% \pm 0.01$, respectively).

The analysis of the essential oils from the leaves and stems of $P$. pellucida revealed significant differences in the chemical profile of the two oils. The literature reports monoterpenes, sesquiterpenes and phenylpropanoids as the chemical classes of oils from the aerial parts of this species. ${ }^{11,13-15}$ In the present analysis, the percentage of monoterpenes was higher in the leaf oil, whereas the content of sesquiterpenes and phenylpropanoids was higher in the stem oil. Unlike most studies in the literature on the chemical identification of the essential oil from $P$. pellucida, ${ }^{11-15}$ the chemical characterization in the present investigation enabled the unmistakable inference of the distribution of monoterpenes, sesquiterpenes, phenylpropanoids and fatty acid derivatives in the leaf and stem oils.

Both oils were toxic to $T$. urticae and toxicity varied in accordance with the part of the plant from which the oil was obtained. Table 2 displays the estimated lethal concentration estimates $\left(L C_{50}\right)$ for the leaf and stem oil extracted from $P$. pellucida as well as eugenol, which was used as the positive control.

Table 2. Toxicity by fumigation ( $\mathrm{LC}_{50}$ in $\mu \mathrm{L} / \mathrm{L}$ of air) of $P$. pellucida essential oils against $T$. urticae

\begin{tabular}{cccccc}
\hline Oil & $\mathbf{N}$ & DF & Slope & $\begin{array}{c}\text { LC } 50 \\
(\mathrm{Cl} 95 \%)\end{array}$ & $\chi^{2 \mathrm{c}}$ \\
\hline Leaves & 627 & 4 & $\begin{array}{c}1.43 \\
(1.33-1.52)\end{array}$ & $\begin{array}{c}4 \times 10^{-2} \\
\left(3 \times 10^{-2}-6 \times 10^{-2}\right)\end{array}$ & 3.53 \\
\hline Stem & 540 & 3 & $\begin{array}{c}1.66 \\
(1.479-1.833)\end{array}$ & $\begin{array}{c}1 \times 10^{-2} \\
\left(1 \times 10^{-2}-2 \times 10^{-2}\right)\end{array}$ & 4.26 \\
\hline EU & 540 & 3 & $\begin{array}{c}0.85 \\
(0.77-0.93)\end{array}$ & $\begin{array}{c}4 \times 10^{-3} \\
\left(2 \times 10^{-3}-5 \times 10^{-3}\right)\end{array}$ & 1.52 \\
\hline
\end{tabular}

EU = Eugenol used as positive control. $\mathbf{N}=$ Total number of mites tested, $\mathbf{D F}=$ Degree of freedom. $\mathbf{C l}=$ Confidence interval, $\chi^{2}=$ Chi-square.

The stem oil was approximately fourfold more toxic than the leaf oil, but 2.5-fold less active than the positive control. Differences in the susceptibility of $T$. urticae in fumigation tests involving essential oils from different parts of the same plant have been observed for leaf and stem oils from four species of the genus Croton. $^{27}$

The differences in toxicity between the fumigating action of the leaf and stem oils extracted from $P$. pellucida growing in a fragment of the Atlantic Forest in the city of Salvador, state of Bahia, Brazil, may be attributed to the qualitative and quantitative differences in the chemical constituents identified in the oils. ${ }^{28}$ The evaluation of the oils from $P$. pellucida demonstrated a relationship between the selected parts of the plant for the obtainment of an essential oil with potential acaricidal activity. Based on the methods employed in the bioassays, the 
toxicity of the oil vapors (fumigating action) was due to the penetration of these vapors into the airways of the mite.

The present findings indicate that leaf and stem oils are chemically different, with a greater amount monoterpenes in the leaf oil and greater amounts of sesquiterpenes and phenylpropanoids in the stem oil. This is the first record of the acaricidal activity of essential oils from $P$. pellucida (leaves and stems) against an important agricultural pest. The essential oils from $P$. pellucida, especially the stem oil, demonstrated strong acaricidal activity. These data suggest that this oil could be used as an alternative to synthetic acaricides for the integrated management of T. urticae. However, further studies are needed for a cost-benefit assessment of this oil in the formulation of a plant-based acaricidal agent as well as the evaluation of its action with regard to non-target organisms and host plants in order to ensure safe use of these naturally-occurring pesticides.

\section{Acknowledgment}

The authors are grateful to the Brazilian fostering agencies Conselho Nacional de Desenvolvimento Científico e Tecnológico (CNPq [National Council for Scientific and Technological Development]) and Coordenação de Aperfeiçoamento de Pessoal de Nível Superior (CAPES [Coordination for the Advancement of Higher Education Personnel) for granting a scholarship and funding for this study (Universal, No. 477778/2013-5 and PQ-2 302860/2016-9).

\section{References}

${ }^{1}$ Abere, T. A.; Okpalaonyagu, S. O. Pharmacognostic evaluation and antisickling activity of the leaves of Peperomia pellucida (L.) HBK (Piperaceae). African Journal of Pharmacy and Pharmacology 2015, 9, 561. [CrossRef]
${ }^{2}$ Bessiere, M. J.; Menut, C.; Lamaty, G.; Joseph, $H$. Variations in the volatile constituents of Peperomia rotundifolia Schlecht. \& Cham. grown on different hosttrees in Guadeloupe. Flavour and Fragrance Journal 1994, 9, 131. [CrossRef]

${ }^{3}$ Xu, S.; Li, N.; Ning, M.-M.; Zhou, C.-H.; Yang, Q.-R.; Wang. M.-W. Bioactive compounds from Peperomia pellucida. Journal of Natural Products 2006, 69, 247. [CrossRef]

${ }^{4}$ Bojo, A. C.; Garcia, E. A.; Pocsidio, G. N. The antibacterial activity of Peperomia pellucida (L.) HBK (Piperaceae). Asia Life Sciences 1994, 3, 35. [Link]

${ }^{5}$ Ngueguim, F. T.; Khan, M. P.; Donfack, J. H.; Tewari, D.; Dimo, T.; Kamtchouing, P.; Maurya, R.; Chattopadhyay, N. Ethanol extract of Peperomia pellucida (Piperaceae) promotes fracture healing by an anabolic effect on osteoblasts. Journal of Ethnopharmacology 2013, 148, 62-68. [CrossRef]

${ }^{6}$ Sangsuwon, C.; Jirujchariyakul, W.; Roongruangchai, K. Chemical constituents and antiamoebic of methanolic fraction from Peperomia pellucida (Linn.) Kunth. Applied Mechanics and Materials 2015, 709, 417-421. [CrossRef]

${ }^{7}$ Khan, M. R.; Omoloso, A. D. Antibacterial activity of Hygrophila stricta and Peperomia pellucida. Fitoterapia 2002, 73, 251. [CrossRef]

${ }^{8}$ Pappachen, L. K.; Chacko, A. In-vitro antioxidant activity and determination of total phenolic, flavonoid contents of Peperomia pellucida Linn. American Journal of Pharmacy and Health Research 2013, 1, 93. [Link]

${ }^{9}$ Aziba, P. I.; Adedeji, A.; Ekor, M; Adeyemi, O. Analgesic activity of Peperomia pellucida aerial parts in mice. Fitoterapia 2001, 72, 57. [CrossRef]

${ }^{10}$ Blank, M. F. A.; Dmitrieva, E. G.; Franzotti, E. M.; Antoniolli, A. R.; Andrade, M. R.; Marchioro, M. Anti-inflammatory and analgesic activity of Peperomia pellucida (L.) HBK (Piperaceae). Journal of Ethnopharmacology 2004, 91, 215. [CrossRef] [PubMed]

${ }^{11}$ Oloyede, G. K. Chemical composition, toxicity, antimicrobial and antioxidant 
activities of the essential oil of Peperomia pellucida (Piperaceae) from Nigeria. International Journal of Essential Oil Therapeutics 2010, 4, 143. [Link]

${ }^{12}$ François, T.; Michel, J. D. P.; Vyry, W. N. A.; Fabrice, F. B.; Lambert, S. M.; Henri, A. Z. P.; Chantal, M. Composition and antifungal properties of essential oil from five plants growing in the mountainous area of the west Cameroon. Journal Essential Oil-Bearing Plants 2013, 16, 679. [CrossRef]

${ }^{13}$ Verma, R. S.; Padalia, R. C.; Goswami, P.; Chauhan, A. Essential oil composition of Peperomia pellucida (L.) Kunth from India. Journal of Essential Oil Research 2015, 27, 89. [CrossRef]

${ }^{14}$ Silva, M. H. L.; Zoghbi, M. G. B.; Andrade, E. H. A.; Maia, J. G. S. The essential oils of Peperomia pellucida Kunth and $P$. circinnata Link var. circinnata. Flavour and Fragrance Journal 1999, 14, 312. [CrossRef]

${ }^{15}$ Moreira, D. L.; Souza, P. O.; Kaplan, M. A. C.; Guimarães, E. F. Essential oil analysis of four Peperomia species (Piperaceae). Acta Horticultcurae 1999, 500, 65. [CrossRef]

${ }^{16}$ Navajas, M.; Migeon, A.; Estrada-Peña, A.; Mailleux, A. C.; Servigne, P.; Petanovic, R. Mites and ticks (Acari). BioRisk 2010, 4, 149. [CrossRef]

${ }^{17}$ Aslan, I.; Özbek, H.; çalmaşur, Ö.; Şahin, F. Toxicity of essential oil vapours to two greenhouse pests, Tetranychus urticae Koch and Bemisia tabaci Genn. Industrial Crops and Products 2004, 19, 167. [CrossRef]

${ }^{18}$ Araújo, M. J. C.; Camara, C. A. G.; Born, F. S.; Moraes, M. M.; Badji, C. A. Acaricidal activity and repellency of essential oil from Piper aduncum and its components against Tetranychus urticae. Experimental \& Applied Acarology 2012, 57, 139. [CrossRef]

${ }^{19}$ Pontes, W. J. T.; Oliveira, J. C. S.; Camara, C. A. G.; Lopes, A. C. H. R.; Gondim Junior, M. G. C.; Oliveira, J. V.; Schwartz, M. O. E. Composition and Acaricidal Activity of the resin's essential oil of Protium bahianum Daly against two spotted spider mite (Tetranychus urticae). The Journal of Essential Oil Research 2007, 19, 379. [CrossRef]
${ }^{20}$ Nascimento, A. F.; Camara, C. A. G.; Moraes, M. M.; Ramos, C. S. Essential oil composition and a acaricidal activity of Schinus terebinthifolius from Atlantic Forest of Pernambuco, Brazil against Tetranychus urticae. Natural Product Communications 2012, 7, 129. [PubMed]

${ }^{21}$ Oliveira, J. C. S.; Dias, I. J. M.; Camara, C. A. G.; Schwartz, M. O. E. Volatile Constituents of the Leaf Oils of Piper aduncum L. from Different regions of Pernambuco (Northeast of Brazil). The Journal of Essential Oil Research 2006, 18, 557. [CrossRef]

${ }^{22}$ Van den Dool H.; Kratz P.D. A generalization of the retention index system including linear temperature programmed gas liquid partition chromatography. Journal of Chromatography A, 1963, 11, 463. [CrossRef]

${ }^{23}$ Adams, R. P. Identification of essential oil components by gas chromatography/mass spectrometry. 4a. ed., Allured Publ. Corp., Illions, 2007.

${ }^{24}$ LeOra Software. POLO - PC: a User's Guide to Probit Logit Analysis. LeOra Software, California, 1987.

${ }^{25}$ Knudsen, J. T.; Tollsten, L.; Bergström, L. G. Floral scents - a checklist of volatile compounds isolated by head-space techniques. Phytochemistry 1993, 33, 253. [CrossRef]

${ }^{26}$ Ogunwande, I. A.; Ogunbinu, A. O.; Flamini, G.; Cioni, P. L.; Okeniyi, S. O. Essential oil profiles of some Nigerian medicinal plants. Journal of Essential Oil-Bearing Plants 2009, 12, 225. [CrossRef]

${ }^{27}$ Neves, I. A. \& Camara, C. A. G. Acaricidal activity against Tetranychus urticae and essential oil composition of four Croton species from Caatinga biome in Northeastern Brazil. Natural Product Communications 2011, 6, 893. [PubMed]

${ }^{28}$ Moraes, M. M.; Camara, C. A. G.; Santos, M. L.; Fagg, C. W. Essential oil composition of Eugenia langsdorfii O. Berg.: Relationships between some terpenoids and toxicity against Tetranychus urticae. Journal of the Brazilian Chemical Society 2012, 23, 1647. [CrossRef] 